\title{
Old Testament foundations for Christian hospitality
}

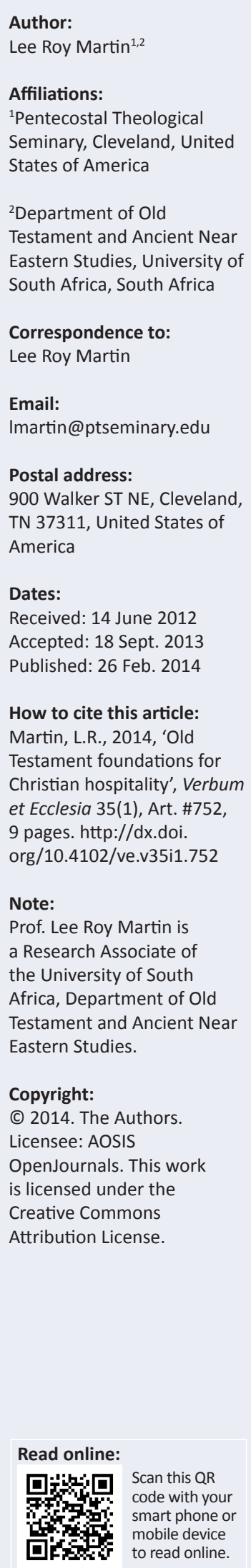

In an effort to revive the ancient Christian practice of hospitality, scholars often appeal to the Old Testament as a model to be emulated. This article examined and described the practice of hospitality in the Old Testament and evaluated its relevancy for the recent discussions surrounding hospitality. Throughout the history of discussions on hospitality, Abraham has served as the exemplar of biblical hospitality. Therefore, the Old Testament practice of hospitality was evaluated through Abraham's story found in Genesis 18. It was concluded that the Old Testament practice of hospitality is not sufficient as a contemporary model for hospitality, but that the following elements of Old Testament thought might serve as theological underpinnings for a renewed and revisioned Christian practice of hospitality in today's multi-faith environment, in that, (1) all humans bear the image of God, (2) all humans are relational creatures, (3) all humans are dependent upon each other and (4) all humans are travellers hosted by God.

\section{Introduction}

The practice of hospitality has been a valuable part of Christian tradition throughout the centuries and efforts are underway to recapture hospitality as a vital and effective means of manifesting the love of Christ in the world (e.g. Bretherton 2006; Jenkins 2007; Pohl 1999; Yong 2008). In the context of increasingly pluralistic, multi-faith societies, it is necessary to construct new and effective paradigms for hospitality. Many communities are now populated with citizens who have little in common with one another and, as a result, each is suspicious of the other. Within these potentially adversarial contexts, the Christian community can serve as host to the 'Other' as a model of God's love to the world. I would argue that any attempt to construct a Christian theology of hospitality must utilise a variety of resources, including theology, Christian tradition, political realities, social customs and the biblical witness.

As a small contribution towards the re-appropriation of hospitality as a Christian virtue, this study addresses the question of how the Old Testament might support a contemporary theology of hospitality within a pluralistic context. Conversations about hospitality often appeal to the social customs found in the Hebrew Bible. These appeals are to be expected because although the word 'hospitality' does not occur in the Hebrew Bible, the practice itself is prominent (Hobbs 2001:4). Unfortunately, however, arguments are sometimes founded upon romanticised readings of the biblical text that misrepresent the Old Testament practice of hospitality (cf. Vogels 2002:162). ${ }^{1}$ Moreover, sociological contextual considerations are often overlooked, leading to the false assumption that customs from 2000 to 4000 years ago can be (and should be) transferred directly to the contemporary context (Vogels 2002:163).

The question of the Old Testament's relevance to the contemporary discussion of hospitality will be explored here in two steps. Firstly, hoping to avoid both a skewed reading of the text and an invalid appropriation of it, I examine closely the Old Testament practice of hospitality in order to determine to what extent the ancient practice is applicable to our multi-faith setting. Secondly, I suggest a number of broader Old Testament theological pillars that can undergird the construction of a revisioned theology of hospitality.

\section{Hospitality in the Hebrew Bible The dominant Old Testament text: Abraham's hospitality}

Throughout the history of discussions on hospitality, Abraham has served as the exemplar of biblical hospitality. His encounter with three 'men' who turned out to be angels is cited repeatedly in Jewish and Christian literature, including Jubilees, Philo, Josephus, 1 Clement, Testament of Abraham, Apocalypse of Paul, Origen, John Chrysostom, Augustine, Genesis Rabbah and the

1.For example, the Old Testament injunction, 'you shall love your neighbour as yourself' (Lv 19:34), continues to be used as support for hospitality, but the Old Testament concept of hospitality involves strangers not neighbours. 
Babylonian Talmud (Arterbury 2003:359-367). The Testament of Abraham (20:15) exhorts, 'Let us too, my beloved brothers, imitate the hospitality of the patriarch Abraham.' The writer of Hebrews, probably alluding to Abraham's experience, admonishes his hearers, 'Do not neglect hospitality ( $\left.\varphi \imath \lambda_{0} \xi \varepsilon v i \alpha_{\varsigma}\right)$, for by this some have unknowingly hosted

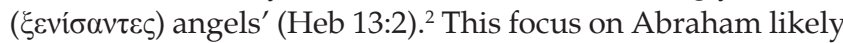
stems from three factors, (1) the status of Abraham in the biblical tradition, (2) the divinely ordered circumstances of Abraham's story and its resultant benefit to Abraham and (3) the completeness of the hospitality model that is displayed in the narrative. In light of the completeness of Abraham's example and its significance in previous discussions, I will utilise his story as a basis for describing the biblical practice of hospitality. Other texts will be brought into the conversation as a supplement to the Abraham narrative.

In Genesis 18:1-16, we find Abraham sitting in the doorway of his tent in the heat of the day, when he sees three unidentified men standing nearby. He runs to greet them and, bowing down in front of them, he urges them to stop and rest under the shade of the tree. Abraham offers to give them 'a little water' with which they can wash their feet. He suggests that after eating a piece of bread and refreshing themselves, they might continue their journey. The travellers accept Abraham's offer and he rushes into the tent and asks Sarah to bake bread and do it quickly. He then hurries outside to slaughter and roast a young calf. Once the food is prepared, he takes it, along with butter and milk, and sets before them a sumptuous feast; and he stands by to serve them as they eat.

At some point during the visit, the men inquire about Abraham's wife Sarah, and Abraham responds, 'She is inside the tent.' One of the men then promises to visit again in the spring and he adds, 'Sarah your wife shall have a son' (v. 10). Sarah, who overhears the conversation, laughs because both she and Abraham are well past the age of having children. The man reassures her saying, 'Is anything too hard for the Lord?' (v. 14). Then the men get up and depart toward Sodom and Abraham goes with them to send them on their way.

\section{A description of Old Testament hospitality}

As stated above, the Abraham narrative is often used as a basis for describing the ancient customs of hospitality. According to Bruce J. Malina (1986), the narrative of Genesis 18 illustrates the three stages in the process of hospitality:

(1.) evaluating the stranger (usually with some test about whether guest status is possible); (2.) the stranger as guest-the liminal phase; (3.) from guest to transformed stranger (at times with another test). (p. 182)

From biblical and other ancient texts, Andrew E. Arterbury (2005) arrived at a definition of hospitality in the ancient Mediterranean world:

At its core, hospitality is the Mediterranean social convention that was employed when a person chose to assist a traveller who

2.The text in Hebrews does not specifically mention Abraham. It is possible, therefore that the author alludes instead to Tobit 7-10, where a scenario similar to Genesis 18 plays out. was away from his or her home region by supplying him or her with provisions and protection. (p. 132)

It has been suggested that the 'main practices stem from nomadic life when public inns were a rarity and every stranger was a potential enemy' (Kooy 1962:654). ${ }^{3}$

Several features of the biblical practice of hospitality are found in the narrative of Abraham's entertaining the angels in Genesis 18.

\section{The object of hospitality is a traveller, not a neighbour and not someone expected}

It is evident from Abraham's greeting that he recognised his visitors as travellers. As he bows respectfully, he pleads, 'My lord, if now I have found favour in your sight, please do not pass your servant by' (v. 3).

The function of hospitality is to transform an unknown person (who may pose a threat) into a guest, thus removing the threat (cf. 2 Sm 12:4; Job 31:32 and other texts) (Hobbs 2001:17). Hospitality was a necessity for nomadic peoples because there were no hotels in the wilderness. Even within the towns and cities there were often no inns available. In the ancient world, travel could be dangerous and a lone traveller (or small group of travellers) would be exposed to attack from robbers and other hostile tribes.

From the perspective of the host, hospitality could be dangerous as well; therefore, hospitality was not offered to everyone. ${ }^{4}$ Two types of travellers would not be welcomed as guests. The first would be traders who moved about in the process of their business (cf. Gn 37). The second would be marauders, wandering throughout the land and taking advantage of every opportunity to plunder and destroy those who were weaker. Both traders and marauders 'are without a home-base, and, as such, are anomalous and regarded with suspicion' (Hobbs 2001:18).

Old Testament hospitality is sometimes characterised incorrectly as kindness offered to the 'stranger'. Although in current English a 'stranger' can mean simply 'a person or thing that is unknown or with whom one is unacquainted', in the Hebrew Bible the term 'stranger' (ger) signifies more specifically a 'sojourner, resident alien' (Clines 2009:70). A stranger (ger), therefore, is not a potentially threatening traveller but is a person who has entered the community from the outside and who has taken up residence more or less permanently (Hobbs 2001:20). Therefore, the stranger (ger) may not be unknown at all; in fact, the stranger might be a neighbour and/or friend and would not be considered a potential threat (Vogels 2002:165). The stranger, or resident alien, is neither required to worship Yahweh nor obligated to perform the ritual commands, but must comply with other

3.See also Ahn (2010:264), who argues that the traveller's presence is an imposition upon the host territory and the traveller is, therefore, 'indebted' to the host. Hospitality, then, is the forgiveness of that debt.

4.Pauw (2011:13-14) observes that even God's hospitality is not without limits. Moab is excluded from the eschatological feast of Isaiah 25 . She cites other examples of God's exclusionary hospitality: Psalms 23:5; Isaiah 65:13; Zephaniah 1:7; Matthew 22:13; Luke 1:53 and Revelation 19. 
laws (such as those regarding labour on the Sabbath). The stranger (ger) is protected by laws in the Mosaic covenant (Ex 22:21; 23:9; Nm 9:14; 15:15; Dt 1:16; 24:17). The Israelites must not oppress or exploit the resident alien. In the Old Testament, there is no case where hospitality is extended to a stranger (ger) (Hobbs 2001:20-21).

The 'foreigner' (nokri) is another category of persons who would be denied hospitality (Clines 2009:274). The foreigner is a non-Israelite who is not a part of the community and who has few rights. The foreigner is characterised as 'an invader, a seducer of Israelite/Judaean women, desecrator of the Temple, a polluter', whose destiny is 'death, slavery, or in rare cases repatriation' (Hobbs 2001:21). Foreigners were avoided partly because of their classification as 'unclean'. The Israelites were prohibited from marrying foreigners and from worshiping foreign gods, though they seem to have been susceptible to both temptations throughout pre-exilic history. In Judges 3:5-6, they are indicted for living amongst the Canaanites, intermarrying with them and for worshiping their gods:

It seems Israel is constantly in danger of being overwhelmed by pollution and sin (the two being distinct) and must constantly protect itself in order to maintain itself as holy and distinct among the nations. (Bretherton 2006:130)

It might be argued that 2 Kings 6:21-24 is an example of hospitality being offered to foreigners. Elisha's giving of food and water to captured Syrian soldiers, however, is 'clearly understood by the Syrian king not as an act of mercy, but as an insult and slight to his honour' (Hobbs 2001:22).

As Hobbs (2001:5-8) has noted, writers often appeal to the customs of hospitality as support for justice on behalf of the poor, immigrants and other marginalised groups, groups that might correspond to the biblical 'stranger' (ger) or 'foreigner' (nokri). But whilst demands for justice are abundant in the Old Testament, hospitality is something else entirely. Old Testament hospitality, therefore, must not be equated with social justice.

\section{Travellers make themselves known, but normally they do not seek out hospitality}

In order to receive an invitation, a traveller must first get the attention of someone who is in a position to serve as host. Thus, 'a traveller in need of hospitality might stand in a place where he or she would be noticed by the residents' (Kooy 1962:654). When Abraham saw the three men of Genesis 18, they were 'standing facing him' (v. 2). Apparently, they had positioned themselves in a location where they could be seen by Abraham and there they waited until Abraham approached. If the location is within a town or city, the travellers might go to an open place and wait for an invitation (Kooy 1962:654). In the case of Genesis 19, the travellers met Lot at the city gate; and in Judges 19, the Levite and his secondary wife waited in the town square until someone offered them hospitality.
Once the travellers have gained the attention of Abraham, they do not approach him or ask for his assistance. Instead, they await Abraham's invitation. Although women were allowed to invite visitors (cf. Gn 24; Ex 2; 1 Sm 25; 2 Ki 4), it was normally the men who accepted that responsibility (Vogels 2002:165). The invitation was offered in the public space, which was considered the realm of the men.

\section{The host extends a modest offer of hospitality}

Abraham says to his potential guests, 'Let a little water be brought, and wash your feet, and rest yourselves under the tree. Let me bring a little bread, that you may refresh yourself' (vv. 4-5). He offers only 'a little water' and 'a little bread' so that the guests will not feel like they are imposing upon their host. According to Vogels (2002):

The visitor has the right to refuse, but this would really be considered an insult to the host, and it could be enough to create hostility and violence. Once the guest accepts the invitation of the host both have then to follow the rules. (p. 16)

After Abraham's modest offer, the travellers are not reluctant to join him. Now that the offer of hospitality has been accepted, the host is free to expand the level hospitality both in quantity and in duration. In the case of Abraham, he and his guests hold to the initial duration of the invitation (less than a day), but the 'little' bread is enlarged to an elaborate banquet that included several loaves of fresh bread and an entire roasted calf.

\section{Hospitality is limited to a fixed period of time}

Abraham's offer of hospitality does not include overnight accommodations. He invites the travellers to wash their feet, eat, and rest, but he says to them, 'after that you may go on' (v. 5). He will not detain them after they have eaten and rested (Arterbury 2003:360). When the travellers respond saying, 'Do as you say', they are accepting Abraham's offer, acknowledging its extent and agreeing to his terms. If both parties agreed, the length of stay could be extended. Visitors often would remain over night, but hospitality was normally limited to no more than 3 days (Hobbs 2001:3; Kooy 1962:654):

If a guest stayed longer, he would become a burden to the host; conversely, if the host kept the guest longer, this could be interpreted as hostility (Gen 24:31, 54-61). (Vogels 2002:166)

\section{Hospitality normally includes water for washing the feet, food, drink, rest and care for any animals}

The first part of Abraham's invitation was an offer of water for the washing of their feet. In the Hebrew Bible, the guests normally wash their own feet (Gn 18:4; 19:2; 24:32; 43:24; Jdg 19:21; $1 \mathrm{Sm} 25: 41 ; 2 \mathrm{Sm} 11: 8) .{ }^{5}$ Whilst the guests were washing their feet and resting, Abraham, Sarah and their servants were busy preparing food and drink, another important element in the custom of hospitality. In the case of Genesis 18, the men were not travelling with any animals, but normally the host would also care for any animals that might accompany the guest (Kooy 1962:654). In Judges 19, for example, the Levite's host 'gave his donkeys fodder' (v. 21; cf. Gn 24:31-32).

5.In later Hellenistic contexts the servants would wash the feet of the guests (Arterbury 2003:361). 


\section{Hospitality is given freely}

Guests are treated with great respect and are not expected to compensate the host, but there is a sense of 'numinous reciprocity' (Koenig 1992:299) that often results in a benefit to the host. For example, custom requires the guest to report any news and to express gratitude (Vogels 2002:166). The expression of gratitude may be in the form of a blessing, as it was in the case of Abraham's visitors, who promised that Abraham's wife Sarah would have a son (vv. 10-14). Through Abraham's generosity and risk, God blesses the host by granting Sarah a child. 'Unexpectedly, the strangers become a harbinger of divine abundance' (Reynolds 2006:199).

Abraham's story is not the only narrative of hospitality in which God is 'discovered redemptively in the meeting' and 'the vulnerable stranger, the one who ostensibly has nothing to offer, becomes a source of enrichment to the reconfigured household' (Reynolds 2006:198). After hosting the angels, Lot and his family are delivered from Sodom, even as fire rains down from heaven (Gn 19). When Abraham sends his servant on a quest to find a wife for Isaac, the event of hospitality serves as the setting for the fulfilment of the divine plan (Koenig 1992:300). The widow of Zarephath (1 Ki 17:8-24), who gives her last bit of food to Elijah, is rewarded by not one, but two miracles. Firstly, she and her son are miraculously sustained through a time of drought in which otherwise they would have died. Secondly, when her son unexpectedly becomes ill and dies, he is raised from the dead through the intercession of Elijah.

These stories that include divine blessings upon the host become the foundation for later encouragements to hospitality (cf. Heb 13:2). The divine involvement in these episodes of hospitality confers upon the practice a heightened significance that leads later Christians to give hospitality a deep theological meaning. For example, M.W. Anderson (1998:643) can say, 'Theologically speaking, the purpose of hospitality is to prepare a welcoming space for encounters with God's word.'

\section{Through hospitality, the host and the guest, who were previously unknown to each other, now enjoy social interaction}

The fundamental purpose of hospitality is to change strangers into guests. Therefore, Malina (1986) writes:

Hospitality might be defined as the process by means of which an outsiders status is changed from stranger to guest ... The outsider is 'received' and socially transformed from stranger to guest ... Hospitality, then, differs from entertaining family and friends. (p. 181)

In the case of Abraham's hospitality, after his three guests have eaten and rested, they display their new found relationship with Abraham (no longer strangers) by promising to return the following year for another visit. One of the guests promises, 'I shall visit you again next year without fail' (vv. 10, 14). ${ }^{6}$

6.The argument of Amos Yong (2008:112-117) could suggest a parallel between the customs of hof A customs of hospitality and the Old Testament's willingness to incorporate nonfrom the ancient Near Eastern from the ancient Near Eastern wisdom tradition and transforms it into a 'friend'. Another example might be the welcoming of Melchizedek as an exemplary priestly figure.

\section{The host accompanies the guests as they depart}

The narrative of Abraham's hospitality concludes according to the standard conventions, with Abraham walking along with his guests as they continue their journey: 'Then the men set out from there ... and Abraham accompanying them to show them the way' (v. 16):

The story of the three visitors clearly shows the hospitality of Abraham, who behaves perfectly according to the social rules of his time. The hospitality described in this story is not accepting strangers or foreigners, nor is it entertaining friends; it is something in between. (Vogels 2002:166)

The rules of hospitality as displayed in the story of Abraham can also be confirmed in other biblical texts, including: Genesis 19:1-11; 24:15-61；29:1-11; Exodus 2:15-22; Judges 19; 1 Samuel 25; 2 Samuel 12; 1 Kings 17:8-16 and 2 Kings 4. However, a number of elements commonly associated with ancient hospitality are not found explicitly in the Abraham story but show up in these other Old Testament hospitality narratives. Three of these elements deserve mention.

Potential guests would be observed closely and, if necessary, questioned in order to determine if they were qualified to receive hospitality: Malina (1986) writes:

Since the stranger is potentially anything, he must be tested as to whether he can subscribe to the rules of the new culture. Officials (Josh 2:2) or concerned citizenry (Gen 19:5) might conduct such tests. (p. 183)

As noted above, not everyone would be welcomed as a guest. The Wisdom of Sirach warns, 'Do not bring every man home with you, for many are the traps of the crafty' (11:29) and 'Bring a stranger home with you and he will start trouble, and estrange you from your own family' (11:34).

Given the fact that Abraham does not impose any test upon his three guests, we might conclude that their physical appearance and demeanour was sufficient to assure Abraham of their worthiness (Vogels 2002:165). Nevertheless, a certain amount of risk was involved for Abraham and for anyone who received unknown travellers. 'For Abraham, alone in the desert, security was dependent on the good intentions of the strangers' (Gibble 1981:185). In one notorious biblical example, Joshua fails to discern the deceptive intent of his Gibeonite guests and ends up causing problems that endured for generations (Jos 9:3-27). Reynolds (2006) elaborates on the risk that must be assumed by the host:

Space is made within the household for the stranger, and this act depends upon a presumption of goodwill and favour that could be abused or violated ... There are no guarantees ... the host simply welcomes another, trusting that-on the basis of a shared humanity-there is a good at hand. Such trust places one in the hands of another, dependent on his or her goodwill. Stated negatively, this entails the risk of letting go of protective prejudgments, assumptions, and expectations. (p. 197)

This ancient model of qualified acceptance might be considered as insufficient for a Christian approach to hospitality. A Christian model would presuppose the giving 
of oneself for the other in ways that are unqualified and unconditional, based upon the rule of loving one's neighbour as oneself.

Hospitality includes a guarantee of protection for the guest: During Abraham's show of hospitality, there was no opportunity for him to demonstrate his protection of his guests; however, in other Old Testament stories, we find this element to be central to the meaning of the narrative. In Genesis 19, after Lot brings the three visitors into his home, the men of Sodom surround the house and demand that he turn over the guests. But as host, Lot is obligated to protect his guests. His sense of duty is so strong that he offers to turn over his own daughters in place of the guests. Lot says:

Now behold, I have two daughters who have not had relations with man; please let me bring them out to you, and do to them whatever you like; only do nothing to these men, inasmuch as they have come under the shelter of my roof. (v. 8)

Lot's offer 'illustrates in an extreme way that the guest is sacred to the host' (Vogels 2002:168).

A similar scenario unfolds in Judges 19, when the Levite and his secondary wife find lodging with an old man in Gibeah. That night, the house was surrounded by men of the town who demanded that the old man turn over the Levite to them. The old man replied, 'No, my fellows, please do not act so wickedly; since this man has come into my house, do not commit this act of folly' (v. 23). He then offered to turn over his daughter and the Levite's secondary wife. Apparently, the laws of hospitality did not protect women to the same degree that they protected men, a fact which is uncomfortable to modern readers and which demonstrates the danger of applying ancient texts directly to contemporary contexts. The point is made, however, that hospitality included a guarantee of protection, and fulfilment of the custom was a matter of honour.

Hospitality adds to the honour of the host: Not only was the protection of one's guest a matter of honour, but the entire custom of hospitality was apparently based upon conventions of honour (Hobbs 2001:4). Hobbs (2001:17) writes, 'The host, in extending his circle of kin and friends, gains in honour by providing' a place for the displaced traveller.

Abraham's story in Genesis 18 does not explicitly state that Abraham gained in honour through his generous hospitality; however, the language of honour is evident in the narrative. As soon as Abraham sees the travellers, he runs out to meet them and honours them by bowing 'down to the ground' (v. 2). He then addresses the travellers in terms that indicate deep respect and seriousness: 'My Lord, if I have found favour in your eyes, please do not pass by your servant' (v. 3). The expression 'if I have found favour in your eyes' often introduces a weighty request (Gn 19:10; 30:27; 32:6; 33:8, 10, 15; 47:29; 50:4; Ex 33:13; 34:9; Nm 11:11; Jdg 6:17; Rt 2:13; 2 Sm 14:22; Neh 2:5). Abraham's solemn request is that the travellers do not 'pass by'. Perhaps Abraham sees this occasion for hospitality as an opportunity to enhance his standing as a man of great honour. Vogels (2002:165) argues, therefore, that this 'text illustrates clearly that hospitality is motivated by the honour of the host. For these visitors to stay would honour Abraham, who does not even wait for their acceptance'.

\section{Dangers and limitations of the Old Testament model of hospitality}

\section{The risk of hospitality}

Hospitality has always involved a certain amount of risk. In the world of the Old Testament, life was a:

struggle against the elements over which humans had no control, but it was also against perceived hostile forces, who were members of groups outside one's own moral community of close kin. (Hobbs 2001:7)

Social structures and customs have changed significantly over the centuries and so have the conventions of hospitality. There may be areas of the world where ancient practices of hospitality still hold true, but for most of the world, hospitality has evolved into a custom quite different from that of biblical times. If we are to envision new ways of thinking about hospitality in a multi-faith environment, we must create new approaches to hospitality, whilst retaining the basic definition that hospitality means to change the Other, 'the unknown friend, into a guest' (Vogels 2002:172).

Concerns for safety are legitimate and those concerns are evident in the ancient practice of hospitality. Not all people who present themselves as needy travellers are harmless in their motives. Deception is always a possibility, and that is why 'Israel's openness to the stranger was not unrestrained' (Yong 2008:111). The inherent risks, however, did not prevent the Israelites and the early Christians from practicing hospitality. The text of Hebrews suggests that its first readers were suffering severe persecution; nevertheless, 'the writer reminded them to practice hospitality, affirming that messengers from God are sometimes thereby received (Hebrews 13:2)' (Morgan 1998:536).

\section{Weaknesses of hospitality as practiced in the Old Testament}

The Old Testament practice of hospitality is relevant to our contemporary situation but some aspects of the practice must be abandoned. Ancient hospitality is insufficient as a model within our multi-faith context. ${ }^{7}$ It must be broadened and deepened if it is to become a Christian model. Several weaknesses of the Old Testament practice should be noted.

Firstly, the choice of guests was limited to travellers. Old Testament hospitality was extended only to travellers and only for short periods of time (Hobbs 2001:28). We need an expanded practice of hospitality that enables us to live together as neighbours with people who are unlike us. We must be willing to display the love of God in ongoing relationships with our non-Christian neighbours and acquaintances.

7.See the argument of Hobbs $(2001: 3-30)$. 
Secondly, the choice of guests excluded aliens and foreigners. As noted above, the Old Testament practice of hospitality was a welcoming of unknown persons who did not appear to be very different from the host. We find that in Judges 19, the travelling Levite is afraid to spend the night in Jebus, because it was not an Israelite city and it might pose a danger. Vogels (2002) writes:

Any reader of the Bible is aware of the numerous conflicts, wars, and barbarism that are described, not only by the nations, the 'others', but also by Israel itself. All these texts are, thus, a counter-witness to hospitality. (p. 163)

The Old Testament message challenges Israel to be a separate and unique people. In the Old Testament context where idolatry was prevalent, the call to separateness is expected. In today's context, however, where many Pentecostal's are being influenced by right-wing fundamentalism, we do not need a call to separation from other religions. Fundamentalism does not engage the Other; rather, it demonises, opposes, and alienates the Other. We need instead a challenge to engagement and neighbourliness. Engagement, however, does not mean that we compromise our theological stance regarding Christ as the only saviour. The perspective of the Old Testament and contemporary fundamentalist Christianity views foreigners as suspicious and discourages contact with them. These are the very attitudes that a Christian paradigm for hospitality should seek to avoid.

Thirdly, ancient hospitality was primarily a patriarchal practice. Normally, it was the men who decided which travellers should receive hospitality. Women were often either subservient or, even worse, they were abused. Vogels (2002) observes that:

Abraham gives orders to his servants and to Sarah, whom he treats like a servant, and they have to prepare the meal; she is not even present to the visitors-she is in the kitchen even though the promise certainly concerns her. (p. 164)

Fourthly, the practice was limited in its goals. The customs of hospitality guaranteed that a traveller could obtain food, shelter and protection. These were the basic needs for a traveller in the ancient world. Today, however, we must offer a kind of hospitality and neighbourliness that is dynamic and creative. Hospitality in some parts of the world includes more than the basics. For example, in addition to the universal aspects of hospitality, such as food and drink, African hospitality includes singing and dancing together (Gathogo 2006:28). We must be able to respond to a multitude of variable needs that are around us. People still need food, shelter and protection, but they also need clothing, education, transportation, community and much more. Therefore, the Old Testament practice of hospitality can contribute to a paradigm of Christian hospitality, but it is not sufficient alone.

\section{The contribution of Old Testament theology to a theology of hospitality}

A major hindrance to hospitable relationships is fear of the difference between us and others. We have neighbours who enjoy different ancestries, speak different languages, observe different customs and practice different religions. These differences create barriers to understanding and the lack of understanding inhibits the forging of relationships. Kristin Johnston Largen (2010:436) concludes that the practice of hospitality is extraordinarily difficult, as at every turn our egos, our tempers, and our self-righteousness get in the way of our genuine openness to another'.

As a first move toward a theology of hospitality, therefore, I would suggest that we focus our attention firstly on the similarities of all humans and then secondly on our diversity. Our commonalities can bring us together to a place of mutual sharing - koinonia, if you will - and then our differences can make our relationships interesting, exciting and stimulating. I would suggest that the Old Testament witnesses to a number of shared human traits that can undergird a broadened contemporary theology of hospitality.

\section{All humans bear the image of God}

Although humans vary in appearance and in culture, those variations are limited and of all humans it can be said that they are made in the image of God. God's intention for humanity is recorded in his hortatory statement, 'let us make humanity in our image, according to our likeness', and is confirmed in the narrative statement, 'So God created the human in God's own image ... male and female God created them' (Gn 1:26-27). The connection between hospitality and the imago Dei is an important link that was recognised by Gregory of Nyssa. Greg Voiles recently examined the place of the practice of hospitality within the Trinitarian theology of Gregory and, according to Voiles (2007:183), Gregory 'theologically "makes space" for the practice of hospitality as an avenue for the renewal of the imago Dei or imago Trinitatis in humanity'.

The practice of hospitality within a multi-faith context requires a transformation in our thinking about the Other. In fact, we must go deeper than our thinking; we need a transformation of our precognitive disposition, so that we are no longer suspicious of those who are different from us. Through training and through prayer we can come to see all people as bearers of God's image and therefore worthy of our respect and our hospitality. Thomas Ogletree (1985) writes:

Regard for strangers in their vulnerability and delight in their novel offerings presuppose that we perceive them as equals, as persons who share our common humanity in its myriad variations. (p. 3)

\section{All humans are relational creatures}

Humanity was created for relationship, social interaction and community. After creating the human, God says, 'It is not good for the human to be alone' (Gn 2:18). ${ }^{8}$ Our model of hospitality should address the 'aloneness' that is experienced by the marginalised people around us (Vogels 1978:9-35). Moreover, the relationship fostered by hospitality

8.1 use the term 'human' and not 'man' because gender did not exist before Eve was created. 
is reciprocal. Both the giver of hospitality and the receiver of hospitality will benefit from the relationship.

The contemporary Christian community, however, must overcome a number of systemic obstacles to hospitality. Western constructs of privacy and individualism, coupled with the domination of everyone's daily agenda by materialistic aspirations, militate against the openness and spontaneity that are required for a lifestyle of hospitality. Families with children often feel obligated to participate almost daily in some kind of extracurricular activity, sports team, community event, or entertainment. Morgan (1998:539) remarks that 'life becomes defined by events on a calendar and not by people with whom one can share God's grace', but Morgan's assertion is not the only possible approach to the busy calendar. A lifestyle of hospitality would turn the activities mentioned above (which can be obstacles to hospitality) into opportunities for showing hospitality. Events on the calendar often include social interaction with persons who are in need of hospitality; therefore, a Christian approach to the busy schedule would be to approach it with spontaneity, remaining always open to the possibilities that present themselves for demonstrating hospitality.

\section{All humans are dependent upon each other}

Beyond the need for community, humans depend upon one another in multiple ways. Bretherton (2006:127) argues that the recognition of common need 'directs one to include the stranger within one's communal relationships'. The Old Testament takes into account our mutual dependency and requires that the stronger members of the community care for the weaker members. Widows, orphans, resident aliens, the sick, and the poor are particularly needy and vulnerable; therefore, the law provides safeguards for their protection. The Old Testament law imposes strong penalties for oppressing the weak. Beyond these specific categories of dependent persons, the Old Testament declares that all of humanity is heavily dependent upon each other and upon God. Writing from the perspective of the wisdom tradition, Qohelet writes:

Two are better than one ... For if either of them falls, the one will lift up his companion. But woe to the one who falls when there is not another to lift him up. Furthermore, if two lie down together they keep warm, but how can one be warm alone? And if one can overpower him who is alone, two can resist him. A cord of three strands is not easily broken. (Ec 4:9-12)

Hospitality highlights the mutual dependency of host and guest. The guest is obviously in a position of need and Reynolds (2006:197) argues that the guest 'has inherent value as a human being precisely in his or her dependence, lacking the ability to reciprocate in kind'. But the host is dependent as well and understands that she or he will someday stand in need of hospitality (Kooy 1962:654). 'It is, in part, the hosts' own sense of vulnerability that allows them to offer recognition and respect to other vulnerable persons' (Pohl 1995:135).
In today's world, we are dependent upon thousands of other people for our daily existence. If we should consider the number of persons who are involved in the production and operation of our food, our transportation, our homes, our education, our employment, our health care and our church, the magnitude of the human matrix of dependency becomes staggering. Unfortunately, we take for granted this complex human dependency, viewing the whole thing impersonally and at a distance, and we continue to imagine ourselves as self-sufficient and independent. Christians recognise ourselves as a constituent of God's larger creation and dependent upon God and upon others for our safety and well-being. Therefore, in obedience to Christ's command to 'do unto others as you would have others do unto you' (Mt 7:12), we are compelled to open our doors to the Other needy humans that surround us, whether they be white or black, rich or poor, Baptist or Muslim, Mexican or Japanese. Pohl (1995) insists:

The normative practice of hospitality, which in addition to providing food and shelter to strangers also includes recognition, community, and the possibility of transcending social difference, requires hosts who are in some way marginal to prevailing social structures and meanings. Without this marginal dimension, the relation between hosts and guests often serves the more conservative function of reinforcing existing social relations and hierarchies. (p. 124)

\section{All humans are travellers hosted by God}

If the purpose of hospitality is to 'nourish and protect travellers who find themselves in a hostile environment' (Koenig 1992:299), then everyone needs hospitality because, to some degree, we all, like travellers, are 'out of place' (Hobbs 2001:17). The Old Testament suggests that we are all strangers, travellers in an alien land (Ogletree 1985:7), who enjoy the hospitality that is extended to us from God by virtue of his ultimate ownership of all creation. This assertion does not create boundaries; rather, it destroys all boundaries, because all of humanity is gathered together under the theological category of stranger and sojourner. Therefore, 'the starting point of Christian hospitality lies in the hospitality of God rather than in the good will of a fellow human being' (Ahn 2010:247).

Gregory of Nyssa proposed that when God created the world, God prepared it as a rich and abundant garden that would serve as a place to host humanity. The first humans were able to enjoy what God had provided for them and were not required to seek for sustenance or communion outside the garden sanctuary. And just as God made space in creation for humanity to enjoy the divine and earthly goods, so we make space to host the Other in our midst' (Voiles 2007:196). Therefore, in hospitality, 'Genesis is recapitulated' so that new creation arises from chaos (Bretherton 2006:112). God's hospitality, however, is more than a model to be imitated. Vosloo (2004) argues:

The Christian moral life is not merely about imitating or imagining differently, but about participation in the life of the triune God. Therefore the Triune life is not merely a model or inspiration, but also the source that enables a Christian moral 
life. This does not diminish the importance of imagination, but it does qualify faithful Christian imagination as being a participatory imagination (or an imaginative participation). (pp. 83-84)

Therefore, when we engage in hospitality, we are more than imitators of God or the imaginers of a new way of being, we become participants in God's hospitable life.

In light of God's status as creator, the Old Testament declares that humans are sojourners on the earth ( $\operatorname{Lv} 24: 23)$ and that the 'earth is the Lord's, and all it contains, the world, and those who dwell in it' (Ps 24:1; cf. Ex 9:29). By sending down manna from heaven and by bringing water from the rock, God extended his hospitality to Israel as they travelled through the wilderness (Ex 16-17). Whilst encamped at Mount Sinai, the elders of Israel were invited by God to come up to the mountain where they 'beheld God, and they ate and drank' with God (Ex 24:11). The psalmist portrays God as perpetual host when he says to God, 'You prepare a table before me'; and just as Abraham's guest promised to return, the psalmist declares, 'I will return to the house of God forever' (Ps 23:5-6). God's role as host extends far beyond Israel and God welcomes into his care all of humanity, the animals and even the plants (Ps 104:10-21). He gives 'drink to every beast of the field' (v. 11) and a dwelling place for the 'birds of the heavens' (v. 12). He provides grass for the 'cattle' (v. 14) and he gives 'vegetation', 'wine', 'oil' and 'food which sustains man's heart' (v. 15). Even the 'trees ... drink their fill', whilst the 'young lions ... seek their food from God' (vv. $16,21) .{ }^{9}$

Pohl (1995:127) maintains that an understanding of the people of God as stewards or tenants rather than as owners runs through the Old and New Testaments'. Even after they had settled in the Promised Land, the Israelites regarded themselves theologically as aliens and sojourners. They were to recite the confession, 'My father was a wandering Aramean' (Dt 26:5). In the same vein, the psalmist declared, 'like all my ancestors, I am a sojourner' (Ps 39:12):

As the covenanted people of God were themselves aliens, and remain vulnerable sojourners with God, provided for and loved by God (Lv 25:23), so too they should love others ... All human beings are strangers in one sense or another. (Reynolds 2006:196)

The Lord warned the Israelites that they should continue to view themselves as the Lord's guests saying, 'land is mine; you are sojourners' (Lv 25:23). Even when harvesting their crops, they were to remember that the land belonged to God and they should leave a portion of their crops for gleaning by the poor (Bretherton 2006:127). The Israelites, therefore, 'were to view themselves as tenants or stewards, living in the land by God's permission and grace' (Pohl 1995:125; cf. Yong 2008:110).

God's role as host culminates in the eschaton, when God will gather all of renewed creation to himself. Although God's

9.Humanity as sojourners is, of course, only one of many descriptive metaphors found in the Old Testament. Humans are also described as God's flock, God's servants, God's subjects and God's family, none of which suggest the need for hospitality. eschatological hosting of creation is described most fully in the New Testament, the Old Testament supplies hints and insinuations. Abraham was called to be a blessing to all the 'families of the earth' (Gn 12:3) and thus God's promise of blessing upon Abraham and his descendants was proleptic of God's blessing upon the whole earth.

God's eschatological hospitality is set forth beautifully in Isaiah 25, which reads:

And the Lord of hosts will prepare a lavish banquet for all peoples on this mountain ... And on this mountain he will swallow up the covering which is over all peoples, even the veil which is stretched over all nations. He will swallow up death for all time, and the Lord God will wipe away the tears from all faces. (vv. 2-6)

The Lord will serve as host for a 'lavish banquet' and the guests will include not only Israel but also 'all peoples'. This rich feast will take place 'in this mount', the place of God's dwelling, that is, God's home. In addition to the feast that God prepares, God will also 'swallow up the veil that is stretched over all nations', an action that suggests open disclosure and the restoration of face-to-face communion. In other words, strangers will become friends. The swallowing up of 'death' and the wiping away of 'tears' brings to mind the host's obligation to protect the guests from any enemies or threatening powers (Pauw 2011:13). ${ }^{10}$

Although God's hospitality reaches its fulfilment in the eschaton, that is not to say that Christians should postpone their efforts to bring full and unconditional hospitality into the present. After all, the Lord's Prayer includes the following petition: 'thy kingdom come, thy will be done on earth as it is in heaven'. One valuable function of eschatology is to alter the present behaviour of believers, who should live in light of the end. The goal of Christian hospitality should be to reach out to the Other in anticipation of the eschaton, when God will bring together every people, nation, kindred and tongue $(\operatorname{Rv} 7: 9)$.

\section{Conclusion}

This study has shown that the Old Testament practice of hospitality, whilst not directly transferable to our context, offers significant contributions to a theology of hospitality (Hobbs 2001:28-29). An examination of the Old Testament witness reveals a number of theological assertions that can undergird a contemporary Christian theology of hospitality. For example, we find in the Old Testament at least four indicators of humanity's commonality, (1) all humans bear the image of God, (2) all humans are relational Creatures, (3) all humans are dependent upon each other and (4) all humans are travellers hosted by God.

Moreover, for Christians, the Old Testament admonition, 'You shall love your neighbour as yourself' (Lv 19:18) is fundamental to every religious practice. Therefore,

10.It should be noted, however, that other eschatological texts seem to indicate that the nations are excluded and only Israel enjoys God's blessing. For example, Koenig (1992:300) points to Amos 9:13-15 and Joel 3:18. 
hospitality should be 'an outward expression of an inward love for others, whether that expression is lavish or simple, elegant or plain' (Kwatera 1992:94). As a Christian practice, then, hospitality is:

a rich and multi-layered practice that includes at least the following elements: a genuine sense of opening our hearts and minds to the other, which is humility; treating the cherished views of another with respect, which is generosity; and being willing to admit those places where we need correction, which is both asking for and offering forgiveness. (Largen 2010:435)

\section{Acknowledgements \\ Competing interests}

The author declares that he has no financial or personal relationships that may have inappropriately influenced him in writing this article.

\section{References}

Ahn, I., 2010, "Economy of "invisible debt" and ethics of "radical hospitality": Toward a paradigm change of hospitality from "gift" to "forgiveness"', Journal of Religious Ethics 38, 243-267. http://dx.doi.org/10.1111/j.1467-9795.2010.00428.x

Anderson, M.W., 1998, 'Hospitality theology', Christian Century 115, 643.

Arterbury, A.E., 2003, 'Abraham's hospitality among Jewish and early Christian writers: A tradition history of Gen 18:1-16 and its relevance for the study of the New Testament', Perspectives in Religious Studies 30, 359-376.

Arterbury, A.E., 2005, Entertaining angels: Early Christian hospitality in its Mediterranean setting, Sheffield Phoenix Press, Sheffield.

Bretherton, L., 2006, Hospitality as holiness: Christian witness amid moral diversity, Ashgate Publishing, Aldershot.

Clines, D.J.A. (ed.), 2009, The concise dictionary of classical Hebrew, Sheffield Phoenix Press, Sheffield. PMid:19303041
Gathogo, J.M., 2006, 'African hospitality: Is it compatible with the ideal Christ's hospitality?', Svensk Missionstidskrift 94, 23-53.

Gibble, K.L., 1981, 'Hospitality to strangers', Brethren Life and Thought 26, 184-188.

Hobbs, T.R., 2001, 'Hospitality in the First Testament and the "teleological fallacy"', Journal for the Study of the Old Testament 95, 3-30. http://dx.doi. org/10.1177/030908920102600101

Jenkins, D.O., 2007, Hospitality: Risking welcome, Abingdon Press, Nashville.

Koenig, J., 1992, 'Hospitality', in D.N. Freedman (ed.), The Anchor Bible dictionary, vol. III, 1st edn., pp. 299-301, Doubleday, New York.

Kooy, V.H., 1962, 'Hospitality', in G.A. Buttrick (ed.), The interpreter's dictionary of the Bible, vol. II, p. 654, Abingdon Press, New York.

Kwatera, M., 1992, 'Hospitality's bed, table, chair, and lamp: God really loves to have us', Liturgical Ministry 1, 93-97.

Largen, K.J., 2010, 'Response to "the ethical horizon": Fidelity, hospitality, and justice', Journal of Ecumenical Studies 45, 433-439.

Malina, B.J., 1986, 'The received view and what it cannot do: III John and hospitality', Semeia 35, 171-194.

Morgan, H., Jnr., 1998, 'Remember to show hospitality: A sign of grace in graceless times', International Review of Mission 87, 535-539. http://dx.doi. org/10.1111/j.1758-6631.1998.tb00115.x

Ogletree, T.W., 1985, Hospitality to the stranger: Dimensions of moral understanding, Fortress Press, Philadelphia.

Pauw, A.P., 2011, 'Hell and hospitality', Word \& World 31, 13-16.

Pohl, C.D., 1995, 'Hospitality from the edge: The significance of marginality in the practice of welcome', Annual of the Society of Christian Ethics, 121-136.

Pohl, C.D., 1999, Making room: Recovering hospitality as a Christian tradition, Eerdmans, Grand Rapids.

Reynolds, T.E., 2006, 'Welcoming without reserve? A case in Christian hospitality', Theology Today 63, 191-202. http://dx.doi.org/10.1177/004057360606300205

Vogels, W., 1978, "It is not good that the "Mensch" should be alone; I will make him/ her a helper fit for him/her (Gen 2:18)', Église et Théologie 9, 9-35.

Vogels, W., 2002, 'Hospitality in biblical perspective', Liturgical Ministry 11, 161-173.

Voiles, G., 2007, 'Windows of infinite welcome: The iconic nature of hospitality', Wesleyan Theological Journal 42, 183-198.

Vosloo, R., 2004, 'Identity, Otherness and the Triune God: Theological groundwork for a Christian ethic of hospitality', Journal of Theology for Southern Africa 119, 69-89.

Yong, A., 2008, Hospitality and the Other: Pentecost, Christian practices, and the neighbor, Orbis Books, Maryknoll. 